\title{
Innovative technologies for public transport
}

\author{
G. Pede \& A. Agostini \\ ENEA, Italy
}

\begin{abstract}
Transport systems are to the highest degree responsible for urban air pollution and their efficiency affects our daily lives and productivity. New advanced technologies have been developed in order to balance the negative effects of transport - in terms of air pollution - and to improve mobility in city centres. This paper presents, after a short analysis of those effects, the state of the art of some of these technologies and how they can contribute to reduce such negative effects while improving transport efficiency. Among the innovative technologies presented, the so called 'Tram-Train' that offers a direct connection between the city center and the suburbs, eliminating the interchanges between train and public transport system has a specific relevance; the advanced rubber-tyred transport with guided running mode' is also discussed: this system puts together the positive features of Tram systems, being powered electrically, and the flexibility of buses, having an onboard generator or batteries. Other technologies here included are: BEVs (Battery Electric Vehicles), HEV (Hybrid Electric Vehicles), FCEV (Fuel Cell Electric Vehicles). Also the NGFV (Natural Gas Fuelled Vehicles) can represent a solution for urban air pollution, in particular for lowering PM, CO and VOC emissions. The analysis of such technologies underlines how the problem of urban air pollution can be tackled through the adoption of new technologies for public transport systems.
\end{abstract}

Keywords: innovative public transport systems.

\section{Introduction}

Transport system effectiveness has to be rewarded as a vital feature for economic and social development. Nevertheless transportation activities are responsible of several negative effects on environment and human health with heavy consequences on social and economic aspects (negative externalities). In the following paper we consider the three major transport externalities: air pollution, 
noise and accident and propose a comparison among innovative public transport systems.

\section{Negative effects on urban environment of transport system}

All transportation modes consume energy; such energy, at the state of the art of technology, is mostly derived from combustion, mainly of fossil fuels and, in general, of oil-derived. Combustion inevitably produces $\mathrm{CO}_{2}$ and many other substances, depending on specific fuel and combustion characteristics, among others Nitrogen Oxides, Sulphur Oxides, Lead $(\mathrm{Pb})$, Volatile Organic Compounds (VOC), Particulate Matters (PM), apart from Carbon Monoxide (CO) because of not perfect combustion. At certain concentrations, such substances change physical and biological characteristics of the air (mainly of the troposphere) with hard consequences on health, climate and weather precipitations characteristics.

Most of the noxious emissions stay in a small range from the source, some of them, such as $\mathrm{CO}_{2}, \mathrm{NOx}$ and $\mathrm{SO}_{2}$ spread farer, producing effect also in other regions, sometimes, as in the case of greenhouse gases, at planetary level. Vehicular exhaust emissions for regulated pollutants are decreasing in Europe, thanks also to the measures so far adopted by the EU Commission that, through several directives aimed at reducing the pollutant emission, established, step by step, from Euro 0 to the recent Euro 5, more restrictive emissions limits.

Successes obtained are to be ascribed to technological improvements, mainly in the road sector such as reduction in $\mathrm{SO}_{2}$ and $\mathrm{Pb}$ level in fuels for traction or NOx catching with catalyst vehicles. Thanks to entirely new technologies like hybrid electric vehicles with dual mode capacity and fuel cell powered vehicles, in the future will be possible to achieve in urban vehicles zero-emission behavior with no compromise in performance.

It is important to observe that big differences arise in global (from well to wheel) road and rail emissions amounts. Let's have a look to consumption and emissions per passenger transport unit in the Italian case.

Table 1: Specific consumption and emissions in Italy $[\mathrm{g} / \mathrm{pkm}]$. Source: Amici della terra - ENEA (*Trenitalia).

\begin{tabular}{|l|l|l|l|l|l|l|l|l|l|l|l|l|l|}
\hline & \multicolumn{3}{|l|}{$\mathbf{S O}_{\mathbf{2}}$} & \multicolumn{2}{l|}{ NOx } & \multicolumn{2}{l|}{ PM10 } & \multicolumn{2}{l|}{ CO } & \multicolumn{2}{l|}{ NMVOC } & Energy [gep/pkm] \\
\hline & Tot & Urban & Tot & Urban & Tot & Urban & Tot & Urban & Tot & Urban & Tot & Urban \\
\hline Private Vehichles & 0.027 & 0.045 & 0.587 & 0.668 & 0.027 & 0.034 & 5.646 & 16.507 & 1.068 & 3.268 & 34.9 & 60.1 \\
\hline Buses \& Coaches & 0.010 & 0.018 & 0.393 & 0.768 & 0.019 & 0.038 & 0.102 & 0.235 & 0.046 & 0.094 & 10.6 & 18.5 & 0.09 \\
\hline Tram \& Metro & 0.097 & 0.097 & 0.034 & 0.034 & 0.004 & 0.004 & 0.003 & 0.003 & 0.001 & 0.001 & $11^{*}$ & $11^{*}$ \\
\hline
\end{tabular}

Better energetic and environmental efficiency of the rail transport are due to:

- high efficiency of the steel wheels running on steel rails;

- higher motion regularity, as train are bound to rail and do not have to conflict with other vehicles;

- lower incidence of mass and friction losses per user, as train is a collective transport. 
This is true for diesel train too, and, as a matter of fact, specific fuel consumption for a diesel convoy is as low as $1 \mathrm{~L} / 100 \mathrm{~km} *$ ton, compared with $4 \mathrm{~L} / 100 \mathrm{~km}$ *ton (average) for European cars.

Apart from energy consumption and gaseous emissions, vehicles operating are responsible of acoustic emissions. Although noise could represent a very negative feature for quality of life, it stays at very local level so that effective mitigation devices can be adopted in some cases (such as extraurban ways). Nevertheless measures must be taken to reduce acoustic emission at source (vehicles), particularly to reduce noise due to road traffic in the urban areas. Therefore, the European Commissions regulated also noise produced from road vehicles. Despite of such limits, noise from urban traffic is very often higher than wellness thresholds. According to WHO estimations (Concerning for Europe's Tomorrow, 1995), more than $72 \%$ of the European citizens are exposed to noise higher then $65 \mathrm{~dB}(\mathrm{~A})$ and $27 \%$ to levels higher than $75 \mathrm{~dB}(\mathrm{~A})$. Over $55 \mathrm{~dB}(\mathrm{~A})$ psychological and nervous disturbances can be observed. Electrical traction (battery vehicles, fuel cell vehicles and hybrid-electric vehicles) and more conscious NVH (Noise, vibration and harshness) design for body and mechanical parts will hopefully contribute to reduce these harmful effects. As a matter of fact, electric vehicles do not make as much noise as combustion engines.

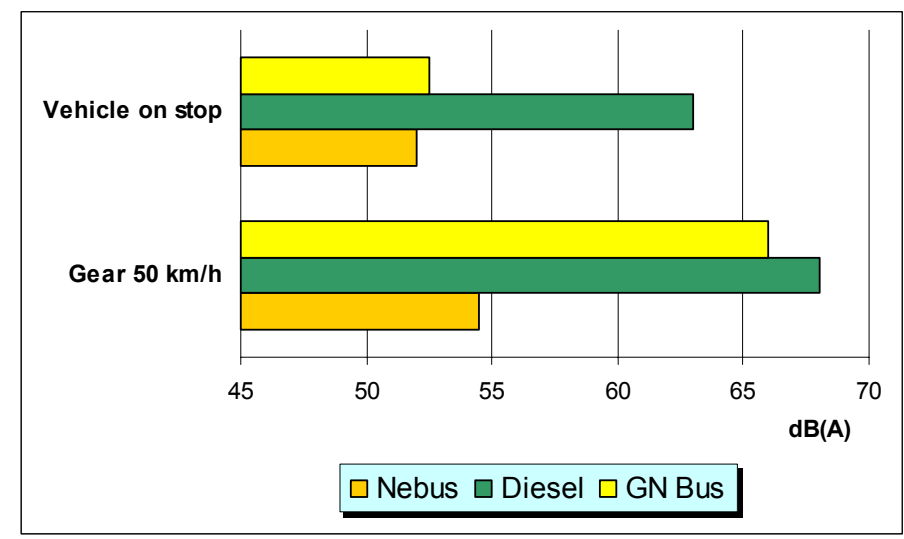

Figure 1: Noise emissions for different bus engine technologies.

Electric vehicles with onboard generation systems (hybrid electric vehicles and fuel cell vehicles) generally make less noise than conventional vehicles because the engine or fuel cells are smaller than a conventional engine and is operated in steady state or quasi steady state mode. Moreover, if the onboard generator is a fuel cell system (like the NEBUS bus), then it is based on an electrochemical conversion principle that is intrinsically quieter than a combustion engine. 


\section{Innovative public transport systems}

The need of urban mobility is nowadays satisfied by various transportation systems with different characteristic and performances according to different utilization demands.

Table 2: $\quad$ Public transport systems characteristic and performances.

\begin{tabular}{|l|l|l|l|l|}
\hline & $\begin{array}{l}\text { Bus and } \\
\text { trolley-bus }\end{array}$ & Tram & $\begin{array}{l}\text { Light rail } \\
\text { Metro }\end{array}$ & $\begin{array}{l}\text { Conventional } \\
\text { metro }\end{array}$ \\
\hline Vehicles capacity (passengers) & $60 \div 120$ & $100 \div 200$ & $100 \div 250$ & $140 \div 280$ \\
\hline Transport capacity (pass/h) & $1500 \div 3500$ & $2000 \div 6000$ & $6000 \div 15000$ & $20000 \div 45000$ \\
\hline Commercial speed (km/h) & $5 \div 20$ & $12 \div 20$ & $18 \div 40$ & $25 \div 60$ \\
\hline Mean stop distance (m) & $150 \div 300$ & $150 \div 300$ & $300 \div 600$ & $400 \div 1000$ \\
\hline
\end{tabular}

It is important to observe again that comparing road and rail systems, the latter are preferable in terms of pollutant emission, and comfort too. Anyway railway systems have high investment costs as well as low flexibility. The need of coping with these problems led to the development of two new transport systems, the tram-train, a tram able to move indifferently on urban tram lines and to travel to over $100 \mathrm{~km} / \mathrm{h}$ on railway lines, and the rubber-tyred transports with guided running mode (tram-bus).

\subsection{Tram-train experience}

A tram-train offers a direct connection between the city centre and the suburbs, eliminating the interchanges between train and urban transport system. The system has extreme flexibility and adaptability, because it is able to move in the pedestrian zones and then to effect the interchange with railway lines or urban protected lane. A ten year service of this transport system in Karlsruhe has showed good operational results, and a growing number of European cities are investigating the TT (tram-train) concept. A key element of this system is the possibility to offer a direct connection with the city centre, eliminating the interchanges between train and urban transport system. This makes the "tramtrain" a competitive and efficient transport system whose success it is not limited to this advantage only, but could offer other positive aspects as:

- reduction of investment costs by using the existing railway infrastructure;

- reduction of trip times that become comparable to private cars;

- greater access facility to the convoy thanks to reduced step and greater doors number;

- extreme flexibility and adaptability of the systems, able to move in the pedestrian zones and then to effect the interchange with railway lines or urban protected lane;

- reduction of the costs of exercise in comparison to the railway since it can be manned by a single driver, and besides it is simple to vary the convoy composition according to the traffic demands thanks to automatic 'hookup'. 
Some project propose a dual mode tram-train vehicle to hoop between consecutive urban stations with autonomous electric traction, thanks to onboard energy supply, generated with a small diesel engine or stored in batteries or ultracapacitors (see later, about innovative electric power trains).

The implementation of an interoperable system is complex, since it needs to consider technological, economic, administrative, normative and political aspects. On a European level the tram-train concept was studied in the RTD project Crossrail (Nr. GRD1-1999-10843), which main aim was to identify barriers to tram-train and cross-border regional rail and subsequent create standards and recommendations that can be used in cities in several countries.

\subsection{Advanced rubber-tyred transport with guided running mode}

Tram systems have got new interest especially if the demand exceed 4000 passengers per rush hours, but they have high investment cost as well as low flexibility. On the contrary, bus and trolley bus offer low comfort, and in addition pollution problems. An intermediate transport system, commonly called 'advanced intermediate rubber-tyred transport with guided running mode' that is of specific interest when the demand is between 2000 and 4000 passengers per rush hour. As examples of such systems, here below are listed the four technologies that nowadays have got a good level in experimentation and application:

- TVR system by Bombardier transport;

- $\quad$ TRANSLOHR by Lohr Ind. in collaboration with Parizzi (Alsthom group);

- CIVIS system by Matra and Irisbus;

- $\quad$ STREAM system by Ansaldo Breda.

Table 3: Main technical characteristic of advanced intermediate rubber-tyred transport systems.

\begin{tabular}{|l|l|l|l|l|}
\hline & CIVIS & STREAM & TRANSLOHR & TVR \\
\hline cross-section $(\mathrm{m})$ & $2.55 \times 3.22$ & $2.50 \times 2.40$ & $2.20 \times 2.89$ & $2.50 \times 3.40$ \\
\hline length $(\mathrm{m})$ & $12 \quad 18$ & $12 \quad 18$ & $25 \quad 32$ & 12 \\
\hline Minimum curve radius $(\mathrm{m})$ & 25 & 12.5 & 10.5 & 12 \\
\hline Vehicle capacity $(\mathrm{p})$ & $70 \quad 120$ & $70 \quad 120$ & $116 \quad 148$ & 145 \\
\hline Commercial speed $(\mathrm{km} / \mathrm{h})$ & $20 \div 25$ & $20 \div 25$ & $20 \div 25$ & $20 \div 25$ \\
\hline $\begin{array}{l}\text { Traction } \\
\text { external supply }\end{array}$ & $\begin{array}{l}\text { twin overhead } \\
\text { line }\end{array}$ & $\begin{array}{l}\text { electric in the } \\
\text { roadway }\end{array}$ & $\begin{array}{l}\text { twin overhead } \\
\text { line }\end{array}$ & $\begin{array}{l}\text { twin overhead } \\
\text { line }\end{array}$ \\
\hline $\begin{array}{l}\text { onboard } \\
\text { diesel-electric }\end{array}$ & batteries & batteries & diesel-electric \\
\hline by-directional & no & no & yes & no \\
\hline
\end{tabular}

Investment and operating cost are lower than tram and light rail metro, the service efficiency is good and the environmental impact is reduced also as regard the historical-architectural structure of the town. Main features of these vehicles are the low environmental impact, thanks to the electric traction, and the dual mode power supply, external, via a overhead line, and autonomous with an 
onboard diesel generator or batteries. In the CIVIS, one of the most innovative of such systems, the impact on infrastructure is nullified by the dual mode guidance, manual and optical: a camera-based system reads coded markings on the ground, while a calculator analyses the image and corrects the vehicle's path thanks to an electric motor connected to the steering column.

\section{Innovative electric and hybrid vehicles}

A number of innovation have been introduced in the last years in urban transport: electric, hybrids, hydrogen and natural gas fuelled traction systems with a very low environmental impact due to the low pollutant and noise emission, that become zero or near-zero when the fuel is hydrogen.

Speaking of reduction in energy consumption, reduction in emissions and reduction in noise and vibrations, among the "environmental friendly" technologies there are advanced propulsion systems like electric drive-train. As a matter of fact, during start up, acceleration and in the lower speed range, lower noise emissions are demonstrated for electric vehicles. At higher speeds, where rolling noise predominates, battery electric vehicles derived from conventional vehicles may be slightly louder than comparable models on account of their heavier weight. In Fig. 2 a comparison between a common car, VW Golf and a similar electric vehicle, the VW City Stromer.

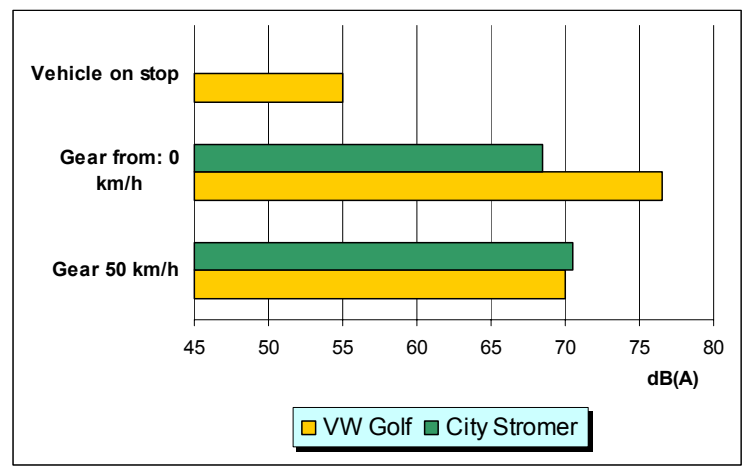

Figure 2: $\quad$ Noise emissions for different car engine technologies.

Hybrid electric vehicles, like the Toyota Prius, are quieter than the conventional ones in every running condition, because in this case the battery pack is much smaller than in a 'pure electric' vehicles. Because low specific energy, 'pure electric' vehicles are used only for 'niche' applications, but hybrid vehicles (HEV) look like a promising solution because they couple some advantages of the traditional technology (e.g. good autonomy of operation) ensured by a chemical energy storage (a fuel) with low emissions although usually they are not strictly ZEV (Zero Emission Vehicles. Today's hybrid market represents relatively low volumes, but car manufacturers like GM and 
Toyota are well placed to meet market as soon as demand develops, demands that could exceed one million units each year

\subsection{BEV, battery electric vehicles}

Electric vehicles are clean (zero emission vehicles) and quiet and can thus make an important contribution to reducing emissions in the cities. However, this is only true directly at their place of operation. If the necessary electricity/energy is produced conventionally, considerable amounts of pollutants continue to be emitted. Only if the energy is provided by regenerative processes (renewable sources), can they be considered true 'zero emission vehicles'.

Because of the limited range, due the low specific energy of battery (in the best case, 1/100 with respect to liquid fuel), just 'niche' application are possible for battery electric vehicles, except for 2 wheel vehicles.

\subsection{HEV, hybrid electric vehicles}

Electric vehicles with a battery system have a range of 80 to $100 \mathrm{~km}$. This means that they are of unrestricted use in inner city traffic where mostly distances of up to $40 \mathrm{~km}$ are covered. For larger distances above $100 \mathrm{~km}$ these vehicles are no alternative to conventional vehicles with combustion engines.

For general purpose use, without range limitations, the most promising solution is HEV, (Hybrid Electric Vehicles) that are vehicles with hybrid (thermal and electric) engine systems. Hybrids are equipped with an electric motor plus an electric Energy Storage System, ESS, (usually batteries) and an "onboard" generator, like a FC or an Internal Combustion Engine (ICE) that converts the fuel energy into electricity. The combination of the emission-free electric engine with the advantages, in terms of range, of the combustion engine working in a quasi steady state (that means with a very low pollutants emissions) are therefore a complete alternative to conventional engines vehicles.

The electrical storage unit is combined with the electric energy generator in order:

- to recover braking energy for a better efficiency;

- to reduce engine (ICE) torque and speed transient, therefore reducing emissions;

- to downsize the generator for achieving the operating point of maximum efficiency of the ICE, thus reducing fuel consumption.

The majority of these vehicles have a storage system composed by a high power battery, in some cases there is a combination batteries/ultracapacitors (UCs).

According to this concept, HEV cars and busses (and also some lorries) have been designed and in some cases mass produced (Toyota, Honda, Ford), by the world's major car makers. They look like a very promising solution because they couple some advantages of the traditional technology (e.g. good autonomy of operation) ensured by a chemical energy storage (a fuel) with low emissions, although usually they are not strictly ZEV (Zero Emission Vehicles).

The continuum of HEV starts from the 'Range extender', electric vehicles with a small generator, 'Dual Mode' hybrid vehicles (Toyota Prius and Estima 
minivan, Ford Escape), that are conventional cars with a limited driving range using only batteries up to conventional vehicles with electrical transmission (diesel-electric) and full power fuel cell vehicles (FCHEV).

Energy Storage Systems (ESS) can be used in railways and metro too for saving energy and stabilize the voltage of the overhead line. The first Energy Storage System world-wide, based on the most innovative technology of Double Layer Capacitors, was put into operation in Cologne by Siemens in May 2001. The first compact Series - Container starts to stabilize the system voltage at Metro de Madrid only one year later, in April 2002, followed by Systems in Dresden/Germany and Portland/USA.

\subsubsection{Hybrid buses on road tests}

In Italy, a national project co-funded by the Ministry of Industry introduced in three Italian cities (Ferrara, Terni, Roma) small demonstrative fleets of hybrid buses for public transport with a small diesel internal combustion engine and a set of batteries. The main aim of this experience was the need of a real evaluation and characterization of a technology that yields promises of reduction of pollutant emission and of energy saving, in view of a possible massive introduction in the congested and polluted urban areas. 24 hybrid buses $(8+4+12$ respectively) produced by the Italian company ALTRA (FIAT + ANSALDO) have been integrated in the urban public transport of each city starting from June 1988. A measurement campaign was performed over the period of one year with onboard instruments, in order to measure the fundamental performances of these vehicles (consumptions, emissions). The results are show in the following table, as expected the small engine working in a quasi-steady way allows one to reduce the pollutant emission but not the consumption.

Table 4: $\quad$ On road measures average values.

\begin{tabular}{|l|l|l|}
\hline & Diesel & Hybrid \\
\hline Fuel consumption $(\mathbf{l} / \mathbf{k m})$ & 0.44 & 0.44 \\
\hline HC $(\mathbf{g r} / \mathbf{k m})$ & 0.82 & 0.59 \\
\hline CO $(\mathbf{g r} / \mathbf{k m})$ & 5.05 & 0.30 \\
\hline NOx $(\mathbf{g r} / \mathbf{k m})$ & 24.92 & 11.55 \\
\hline
\end{tabular}

\subsection{FCEV, fuel cell electric vehicles}

Fuel cell vehicles are electric vehicles where the energy is generated onboard by a fuel cell. Fuel cells are addressed as "zero emission" technology and produce electrical energy at high efficiency. Whether or not the efficiency is higher than that of internal combustion engines such as piston engines and gas turbines depends on factors like:

- primary fuel source;

- type of operation (variable load versus constant load);

- power level.

Several types of fuel cells exist. They are generally (but not always) given names that refer to the electrolyte. 
Table 5: $\quad$ Fuel cells characteristics.

\begin{tabular}{|l|c|l|l|l|l|l|}
\hline \multicolumn{1}{|c|}{ FC Acronym } & AFC & \multicolumn{1}{c|}{ PEMFC } & DMFC & PAFC & MCFC & SOFC \\
\hline Operating temp. $\left[{ }^{\circ} \mathrm{C}\right]$ & 80 & $40-80$ & $60-130$ & \multicolumn{1}{c|}{200} & 650 & 1000 \\
\hline Fuel ${ }^{*}$ & $\mathrm{H}_{2}$ & $\mathrm{H}_{2}\left(/ \mathrm{CO}_{2}\right)$ & Methanol & $\mathrm{H}_{2}\left(/ \mathrm{CO}_{2}\right)$ & $\mathrm{H}_{2}, \mathrm{CO}$ & $\mathrm{H}_{2}, \mathrm{CO}$ \\
\hline Electrolyte & $\mathrm{KOH}$ & Polymer & Polymer & $\begin{array}{l}\text { Phosphoric } \\
\text { Acid }\end{array}$ & $\begin{array}{l}\text { Molten } \\
\text { Carbonate }\end{array}$ & $\begin{array}{l}\text { Solid } \\
\text { Oxide }\end{array}$ \\
\hline First markets & space & $\begin{array}{l}\text { car, bus, } \\
\text { distributed } \\
\text { power, CHP } \\
\text { portable } \\
\text { power, } \\
\text { submarine }\end{array}$ & $\begin{array}{l}\text { portable } \\
\text { power }\end{array}$ & $\begin{array}{l}\text { distributed } \\
\text { power, } \\
\mathrm{CHP}^{* *}\end{array}$ & $\begin{array}{l}\text { distributed } \\
\text { power, } \\
\mathrm{CHP}^{* *}\end{array}$ & $\begin{array}{l}\text { distributed } \\
\text { power, } \\
\text { CHP } \\
\text { APU }\end{array}$ \\
\hline
\end{tabular}

Fuel cells use hydrogen, which can be made of virtually any fossil fuel source and from renewable energy sources (e.g. from biomass, wind and solar energy). Thus, fuel cells help to reduce the dependence of oil, and enable the transition to a sustainable energy system. Fuel cells are modular and can be shaped in various designs. This allows designers to develop new products or to completely redesign existing products.

The progress in fuel cell development is most visible in the area of vehicles. To a large extent, the PEMFC is the technology used here. The driving force here is the Californian legislation with respect to zero emission vehicles. The fact that the Californian legislation is an important factor is clearly demonstrated by listing the companies that make significant progress: GM, DC, Ford, Toyota, Mazda, Nissan and Honda. Currently, small fleets of "prototype" buses and cars are being built. The size of the series of one individual brand and type is $<50$ (the biggest one is the CITARO buses fleet, 30 Daimler Chrysler buses in 10 European cities). These vehicles will mostly use hydrogen as a fuel. Typically, the power level at which stacks and systems now are developed is in the order of $80 \mathrm{~kW}$. Commercialization is foreseen to start in 2010. For buses, this may be somewhat earlier. With respect to the fuel that will be used we have seen some changes over the last ten years. Initially, the research community, taking into account the problems associated with $\mathrm{H}_{2}$ infrastructure and onboard storage, opted for methanol. This liquid fuel is quite easily reformed to obtain a $\mathrm{H}_{2}$ rich gas that can be used in the PEMFC. Later on, the oil companies came into play and opted for gasoline reformers. With gasoline reformers, the existing infrastructure can be used and some problems associated with the use of methanol can be avoided. Since making a gasoline fuel processor is not an easy job, it now seems that several car companies are becoming more and more interested in using $\mathrm{H}_{2}$. The situation may however drastically change as soon as a gasoline fuel processor will be developed. 
Table 6: $\quad$ Effects of the different technologies (* positive - / neutral).

\begin{tabular}{|l|c|c|c|c|}
\hline & Rail systems & Methane & Hybrid Vehicles & FC Vehicles \\
\hline Noxious emission & $* *$ & $*$ & $*$ & $* * *$ \\
\hline Noise & $*$ & $*$ & $* *$ & $* * *$ \\
\hline Energy saving & $* *$ & $/$ & $* *$ & $* * *$ \\
\hline Safety & $* * *$ & $/$ & $/$ & $/$ \\
\hline
\end{tabular}

\section{Conclusion}

The introduction of innovative transport system for public transport in most of Cities and metropolitan areas could improve significantly the effectiveness of local movements both in terms of urban environment and economic efficiency.

Quoting the IEA [7] 'Each additional bus provides large benefits. Regardless of whether a bus is "clean" or "dirty", if it is reasonably full it replaces anywhere from 10 to 40 other motorised vehicles'. We could add that new public transport systems based on environmental friendly technologies, like those presented in this paper, could represent the answer for the future transport systems if we take into account the better safety, the noise reduction, the energy saving, the improvement of the urban environment due to less pollution and less land 'taken' by running or parked cars.

\section{References}

[1] M. Andriollo, G. Del Torchio, G. Martinelli, A. Morini \& A. Tortella Innovative technologies for the public transportation in the Urban Mobility Plan of Padova, VI International Conference on Technologies and Combustion for a clean Environment, Oporto, 2001

[2] KFB report 2000, Hybrid Electric Vehicles: an alternative for the Swedish market?

[3] R. Bittarelli et al. Hybrid Buses and Sustainable Mobility", THERMIEFLEETS report, May 2000

[4] C. Godbersen, Energy storage system based on double layer capacitor technology - the gateway to high efficient improvement of mass transit power supply, $2^{\text {nd }}$ UIC Railway Energy Efficiency Conference, Paris 4-5 February 2004

[5] A. Genovese, R. Ragona, Hybrid Buses consumption and pollutant emissions in operating conditions, Proc. of 10th Int. Symposium "Transport and Air Pollution" September 17-19, 2001 - Boulder, Colorado USA

[6] Amici della terra and ENEA,Valutazione del vantaggio, in termini di minori costi ambientali e sociali,di un forte sviluppo del trasporto collettivo in ambito urbano;

[7] Lew Fulton, New insights from the IEA's worldwide Transit study; IEA;2001

[8] G. Pede, V. Sglavo, M. Conte, G. Mantovani, D. Gostoli, D. Macerata, High power lead-acid battery for heavy-duty HEV, on the road and laboratory performance and reliability assessment, SAE 2003 Transaction, Journal of Engines 